\title{
Amino Acids Diets as a Model for Investigating Cancer Induced by Acrylamide Produced during Wrong Food Cooking
}

\author{
Gamal M Hamad ${ }^{1 *}$, Elsayed E Hafez ${ }^{2}$, Ahmed Khaled ${ }^{3}$ and Amro A Amara ${ }^{4 *}$ \\ ${ }^{1}$ Food Technology Department, Arid Land Cultivation Research Institute, City for Scientific Research and Technological \\ Applications, New Borg AL Arab, Alexandria, Egypt \\ ${ }^{2}$ Plant Protection and Biomolecular Diagnosis Department, Arid Land Cultivation Research Institute, City for Scientific \\ Research and Technological Applications, New Borg AL Arab, Alexandria , Egypt \\ ${ }^{3}$ Agricultural Botany Department, Faculty of Agriculture, Saba-Bacha Alexandria University, Alexandria, Egypt \\ ${ }^{4}$ Head of Protein Research Department and the Scientific Publishing office, Genetic Engineering and Biotechnology \\ Institute, City for Scientific Research and Technological Applications, New Borg AL Arab, Alexandria, Egypt
}

Received: 18 October, 2017; Accepted: 17 January, 2018; Published: 19 February, 2018

*Corresponding author: Gamal M. Hamad, Food Technology Department, Arid Land Cultivation Research Institute, City for Scientific Research and Technological Applications, New Borg AL Arab, Alexandria, Egypt, E-mail : hamad6751@yahoo.com

\begin{abstract}
Starvation could be the cheapest solution for cancer treatment. Alternatively, controlled amino acids diets could be another solution. Starving the body from certain amino acids as well as changing the amount of some used amino acids controlled diet is the main idea of this study. In this study, acrylamide was used to induce cancer in the rats. Acrylamide is a cancer causative agent. We utilize it through a diet containing potato. To evaluate the effect of such change in the cancer cells induced by acrylamide in rats, five diets different in their amino acids constituents were designed. Rats were feed on the different amino acids diets to investigate their effect on the cancer induced by the acrylamide. Biochemical analysis for the liver functions represented by GOT, GPT and ALP assays as well as the amount of the produced billirubin and cholesterol were performed. Additionally the weight and the histo-pathological changes in each of the liver, lung and kidney tissues were investigated. To evaluate the effect of the treatments on the molecular level $\mathrm{P}^{53}$, expression level as a cancer genetic marker were investigated. The results were subjected to logical and statistical analysis. Statistical analyses for the data using LSD were generated. The data obtained from this study prove that the amino acids controlled diets could incapsitate for some extend the development of the cancer cells. In this study, protection against the formation of the cancer is also reported. The main explanation is that such controlled diet might be able to reduce the growth rate of the cancer cells or give suitable time to the cell self-killing mechanism to be complement with the cancer cells replication rate and growing time. Depleting seven amino acids from the diet show the best result (group E). The study prove that vegetarian, those how fasting or starving are safer and can resist cancer. However they are more susceptible to exogenous source of toxins such as the acrylamide than those who include amino acids in their diets. Controlled amino acids diets show different results according to the amino acids composition. This study recommended use of controlled amino acids to save our health And more study for the role of the controlled amino acids diets either in cancer protection, prevention or treatment as well as which amino acid(s) should be depleted from which cancer cells should be conducted.
\end{abstract}

List of Abbreviations: ALCRI ;Arid Land Cultivation Research Institute, AmCF; amphophilic cell foci, BCF; basophilic cell foci, CCF clear cell foci, GOT; Glutamic oxaloacetic transaminase, GPT; glutamic pyruvic transaminase, GR; glutathione reductase, LSD; least significant difference, MCF; mixed cell foci, MN; multiple nucleoli, SAM; S-adenosyl-L-methionine, TB; tumor-bearing, TCF; tigroid cell foci, VH; vacuolated hepatocytes.

\section{Introduction}

'Cancer' is a general term applied to a series of malignant diseases characterized by a rapid and uncontrolled formation of abnormal cells which may mass together to form a growth or proliferate throughout the body. Cancer may progress until it causes the death of the organism. Tumors were classified into two main types: benign and malignant. These two types represent the extreme spectrum of tumor growth, while some tumors may exhibit properties of both types, and others may slowly change from one type to another. Benign tumors proliferate locally and are composed of differentiated cells resembling those of the organs' tissues, where the edge of the tumor is well defined.
Malignant tumors are not encapsulated and their edges are ill-defined. Projections of tumor cells extend from the central mass into surrounding tissue. The most common strategy for cancer treatment includes surgery, radiotherapy, chemotherapy, gene therapy, immunotherapy, and treatment with natural plant products. Severe starvation is another tool used by folk. Controlling cancer using complex amino acids imbalance is a rather new strategy aimed to deplete the cancer cell nutritional requirement by introducing synthetic meals to the patient with a defined percentage of each amino acid lead to the death of the cancer cells. In vivo controlling of amino acids using certain enzymes as L-asparaginase is currently used in the treatment of 
cancer. However, L-asparaginas is heterogenous protein to the human particularly if produced from non-human source. So, it shows immunogenicity. Certain neoplastic tissue, including acute lymphoblastic leukemia cells required an exogenous source of the amino acid L-asparaginase. It was observed that the injected malignant lymphoma cells failed to survive in the guinea pig, and that guinea pig serum prevented the survival of lymphoma cells injected into mice. The explanation lied on the fact that the guinea pig serum contains the enzyme L-asparaginase which destroys the amino acid L-asparagin, which is necessary for the formation of nucleic acids by hydrolysis L-asparagine to aspartic acid and ammonia [1].

Depletion of a single essential nutrient for the cancer cell growth apparently will lead to their death. This fact was proved after the tissue culture technology. Microbial growths as contamination in a cell culture will lead to the cells death mainly by depleting the nutritional resources. Collectively cancer cells are similar to normal cells. But the most important criteria which put a spot on the differences between the cancer cells and the normal cells that cancer cells grow faster than the normal cells hence they are in need for more nutrients.

This observation brings the idea to control cancer growth by controlling the nutrient supplied to the cells [2]. protein free diet was the first to be examined [3]. In fact complete fasting, partial fasting and starvation for certain period or for long time were well known in old civilization either for improving the health or as a part of the religious ceremony. Some ethnic groups are completely vegetarian and others are fasting for long times. Such approach might in need to be re-evaluated while in such age their misunderstand for the ability of the cells to synthesize amino acids from sources other than protein still existed. For that later the scientists start to focus on the essential amino acids and their roles in cancer treatment, while they are the only amino acids in need to be supplied from exo-source [4]. Sugimura, et al. (1959) reported that tumor cells slow down in absence of methionine, isoleucine or valine [5]. Lorinz and Kuttner reported inhibition in patients fed with a diet low in phenylalanine only [6]. Other reports prove the effect of the other amino acids in a certain type of cancer cells [7].

Cancer cells have some main criteria as suggested by Hanahan and Weinberg $(2000,2011)$ and Amara (2011, 2012 and 2013) that essential alterations in the cell physiology collectively direct malignant growth:

- self-sufficiency in growth signals,

- insensitivity to growth-inhibiting (antigrowth) signals,

- evasion of programmed cell death (apoptosis),

- limitless replicative potential,

- sustained angiogenesis,

- tissue invasion and metastasis,

- reprogramming of energy metabolism,

- invading immune destruction,
- cancer cell still qualitatively similar to normal cell and can escape from the immune system,

- Some DNA change or damage should happen to change the normal cells into tumor cells [8-12].

Controlling cancer cells' growth will be so far by using one or more strategy based on the one or more of the cancer unique criteria. Finding differences between the normal cells and the cancer cells are the aim of the scientists. In this study, we reinvestigate and re-evaluate the role of amino acid-depletion and variation in the treatment of cancer induced in rats using acrylamide. The concept and the idea will be described in detail for the proper possibility of controlling cancer cell through diet rather than using the unsafe toxic antitumor compounds even mutagenic.

\section{Materials and Methods \\ Experimental Animal Model}

The experimental animals used in this study were represented in a total of thirty-five albino white male rats of Wistar strain, with weights ranging between $150-200 \mathrm{~g}$ each at the beginning of the experiment. They were obtained from the animal house of the Medical Research Institute, Alexandria-University, Alexandria, Egypt. The animals were maintained on a 12-hour light/12-hour dark cycle at ambient temperature of $(23 \pm 2)^{\circ} \mathrm{C}$ and housed for 7 days before the experiment. Animals were clinically healthy and they were acclimatized to the laboratory condition before being used for two weeks and were allowed food and water adlibitum. Rats were divided into groups of five animals each.

\section{Media Compositions}

The general composition of the feeding media was as follows for each/L:

A. Amino acids $350 \mathrm{~mL}$ (five different groups of amino acids (g/L) as in table 1);

B. Sugar: $300 \mathrm{~mL}$ [Glucose 5 g; Starch 44 g];

C. Corn oil $11 \mathrm{~g} / \mathrm{l}$;

D. Vitamins: stock (prepared in $100 \mathrm{ml}$ ) contain the following vitamins:
1. Vitamin A $0.0040 \mathrm{~g}$;
2. Vitamin B1 $0.0020 \mathrm{~g}$;
3. Vitamin B2 $0.0020 \mathrm{~g}$;
4.Vitamin B6 0.0020 g;
5. Vitamin B12 0.0002 g;
6. Vitamin C 0.0333 l;
7. Vitamin D3 $0.0125 \mathrm{~g}$;
8. Vitamin E $0.3000 \mathrm{~g}$;
9. Vitamin K3 0.0050 g;
10. Folic acid $0.0020 \mathrm{~g}$;
11. Biotin $0.0010 \mathrm{~g}$. 


\section{E. Saline $0.9 \%: 190 \mathrm{~mL}$.}

The volume completed to one $\mathrm{L}$ by water. The rats are given $330 \mathrm{ml} / \mathrm{kg}$ from each of the different prepared medium.

\section{Acrylamide diet for cancer induction}

Rats treated with acrylamide were given $500 \mu \mathrm{g} / \mathrm{Kg}$ body weight acrylamide according to Yousef and El-Demerdash (2006) [13].

\section{Amino Acids Diets}

Amino acids solution was classified into five groups A, B, C, $\mathrm{D}$ and $\mathrm{E}$. The composition of each group is shown in table 1. Five nonessential amino acids are not included.

- Group A contains all fifteen used amino acids.

- Group B contains fourteen amino acids (methionine was depleted).

- Group C consists of fourteen amino acids (valine was depleted).

- Group D contains thirteen amino acids (methionine and valine-were depleted).

- Group E contains thirteen amino acids (methionine and valine-were depleted) and the arginine concentration is duplicated.

\section{The Experimental animal design was as follows:}

- Control represent in Group 1 was given distillated water through gastric lavage (no amino acids pro-vided) and feed on the above described diet (without amino acids).

- Treatment represent in Group 2 was given acrylamide (as above) and feed on the above described diet (without amino acids). Acrylamide given in amount equal to $500 \mu \mathrm{g} / \mathrm{Kg}$ body weight according to Yousef and El-Demerdash (2006) [13].

- Group 3 to 7 which represent those received both of the acrylamide (Acrylamide given in amount equal to $500 \mu \mathrm{g} / \mathrm{Kg}$ body weight according to Yousef and El-Demerdash (2006) and they are feed on the above medium contain the amino acids diet designed for each group as above and as in table 1 [13].

A daily fresh solution of acrylamide dissolved in distillated water was prepared. Each animal had received its weight corresponding dose (according to the fortnight weight) orally, by using a round-head needle syringe. Rats, were fasted overnight before decapitation, and slaughtered at the end of experiment. After 90 days, blood samples were collected from all animals (from the retro-orbital plexus) in clean, dry and labeled tubes containing heparin (10 I.U/ml).

Table 1: Detailed Composition of amino acids solutions (g/L)

\begin{tabular}{|c|c|c|c|c|c|}
\hline Amino acids $g / L$ & Group A & Group B & Group C & Group D & Group E \\
\hline Isoleucine & 5.5 & 5.5 & 5.5 & 5.5 & 5.5 \\
\hline Leucine & 7.5 & 7.5 & 7.5 & 7.5 & 7.5 \\
\hline Lysine & 7.0 & 7.0 & 7.0 & 7.0 & 7.0 \\
\hline Methionine & 6.0 & -- & 6.0 & -- & -- \\
\hline Phenylalanine & 4.0 & 4.0 & 4.0 & 4.0 & 4.0 \\
\hline Threonine & 5.0 & 5.0 & 5.0 & 5.0 & 5.0 \\
\hline Tryptophan & 1.5 & 1.5 & 1.5 & 1.5 & 1.5 \\
\hline Valine & 6.0 & 6.0 & -- & -- & -- \\
\hline Arginine & 6.0 & 6.0 & 6.0 & 6.0 & 12.0 \\
\hline Histidine & 3.0 & 3.0 & 3.0 & 3.0 & 3.0 \\
\hline Proline & 4.0 & 4.0 & 4.0 & 4.0 & 4.0 \\
\hline Tyrosine & 1.0 & 1.0 & 1.0 & 1.0 & 1.0 \\
\hline Alanine & 20.0 & 20.0 & 20.0 & 20.0 & 20.0 \\
\hline Glycine & 7.5 & 7.5 & 7.5 & 7.5 & 7.5 \\
\hline Aspartic acid & 4.0 & 4.0 & 4.0 & 4.0 & 4.0 \\
\hline
\end{tabular}

\section{Oligonucleotides (primers)} study.

MWG Company, Germany, synthesized primers used in this

Primer's sequences are:

$\mathrm{P}^{53} \mathrm{~F}$ 5'-CATCGAATTCTGGAAACTTTCCACTTGAT-3'
and

$\mathrm{P}^{53} \mathrm{R}$

5'-GTAGGAATTCGTCCCAAGCAATGGATGAT-3'

\section{DNA and RNA Preparation from Blood}

To $1 \mathrm{ml}$ whole blood (EDTA, heparin, citrate) $3 \mathrm{ml}$ lysis buffer were added, and the mixture was shaked gently and incubated for $30 \mathrm{~min}$ on ice, and centrifuged at $1200 \mathrm{rpm}$ for $10 \mathrm{~min}$ at $4^{\circ} \mathrm{C}$. Supernatant was Removed, $1 \mathrm{ml}$ lysis buffer was added, the pellet was re-suspend, and centrifuged for $10 \mathrm{~min}$ at $4^{\circ} \mathrm{C}(1200$ rpm). Supernatant was Removed and $0.5 \mathrm{ml}$ SE-buffer was added, 
the pellet was re-suspend, followed by centrifugation for 10 minutes at $4^{\circ} \mathrm{C}(1200 \mathrm{rpm})$. The supernatant was removed and the pellet was frozen. $1 \mathrm{ml} \mathrm{SE}$-buffer was added and the pellet was resuspended, $40 \mu \mathrm{l}$ proteinase $\mathrm{K}(10 \mathrm{mg} / \mathrm{ml})$ was added and $250 \mu \mathrm{l} 20 \%$ SDS, shaked gently, and incubated overnight at $37^{\circ} \mathrm{C}$ in a water bath. A $5 \mathrm{ml} \mathrm{SE}$-buffer was added and $10 \mathrm{ml}$ phenol shaked by hand for $10 \mathrm{~min}$, and centrifuged at $3000 \mathrm{rpm}$ for 5 $\min$ at $10^{\circ} \mathrm{C}$. The supernatant was transferred into a new tube, $1 \mathrm{ml}$ phenol/chloroform/ isoamyl alcohol (25:24:1) was added and shacked by hand for $10 \mathrm{~min}$, and centrifuged at $3000 \mathrm{rpm}$ for $5 \mathrm{~min}$ at $10^{\circ} \mathrm{C}$. The supernatant again was transferred into a new tube, $1 \mathrm{ml}$ chloroform/ isoamylalcohol (24:1) was added, shaked by hand for $10 \mathrm{~min}$, and centrifuged at $3000 \mathrm{rpm}$ for $5 \mathrm{~min}$ at $10^{\circ} \mathrm{C}$. The supernatant was transferred into a new tube; $100 \mu \mathrm{l}$ $3 \mathrm{M}$ sodium acetate ( $\mathrm{pH} 5.2$ ) was added and $10 \mathrm{ml}$ isopropanol, shaked gently until the DNA precipitated (glass pipette was used to make a hook over a Bunsen burner, and capture the DNA. The DNA was washed in $70 \%$ ethanol and dissolved the DNA in 0.1 $\mathrm{ml}$ TE-buffer overnight at $4^{\circ} \mathrm{C}$ on a rotating shaker $[18,19]$. The RNA was prepared using the RNA isolation column kit (Biotech. lnc. USA)

\section{Amplification of $\mathrm{P}^{53}$ Gene from the Purified DNA and RNA}

Purified DNA was subjected to the PCR reaction. 15 minutes initial denaturation step at $95^{\circ} \mathrm{C}$ in the beginning was followed by 30 cycles of amplification. Each cycle consisted of denaturation step at $94^{\circ} \mathrm{C}$ for $1 \mathrm{~min}$ followed by annealing step at $58^{\circ} \mathrm{C}$ for $1 \mathrm{~min}$ and extension step at $70^{\circ} \mathrm{C}$ for $1 \mathrm{~min}$ with ten min delay at $70^{\circ} \mathrm{C}$ at the end of the last cycle as a post extension step. A ramping of

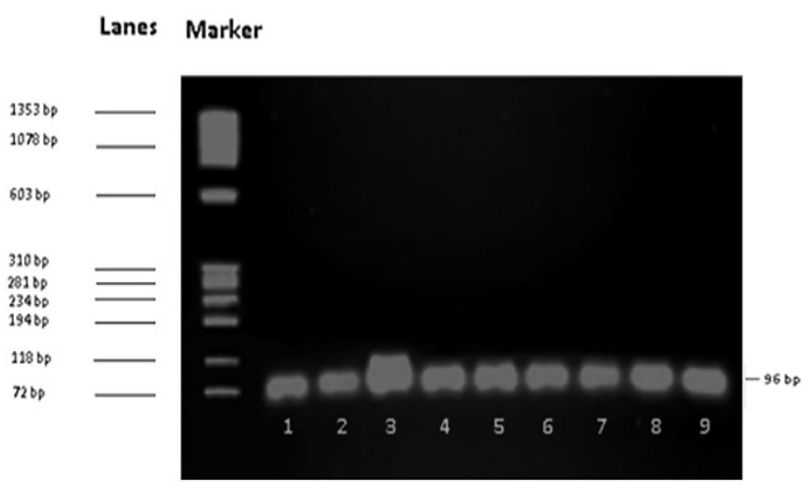

Figure 1: Amplification $\mathrm{P}^{53}$ gene from extracted of DNA from treated and untreated animals. Lane M: IX-174 DNA marker. Lane 1, control Lane $3=$ treatment by (Acrylamide) Lane 4 and $5=$ treatment (A) by $(\mathrm{AA})$ Lane 6 and 7$)=$ treatment $(\mathrm{B})$ by $(\mathrm{AA})$ Lane 8 and $9=$ treatment (C) by (AA)

slower $10 \%$ of the default value modified extension temperature. Amplified products were stored at $-20^{\circ} \mathrm{C}$. The reaction mixture was analyzed by electrophoresis on $1.5 \%$ agarose in $1 \mathrm{x}$ TrisBorate EDTA buffer, stained with Ethidium bromide and visualized under Ultra Violet transilluminator [20]. For amplify the $\mathrm{p}^{53}$ from the extracted total RNA single step program was performed using GeneAmp 9700 thermocycler machine.

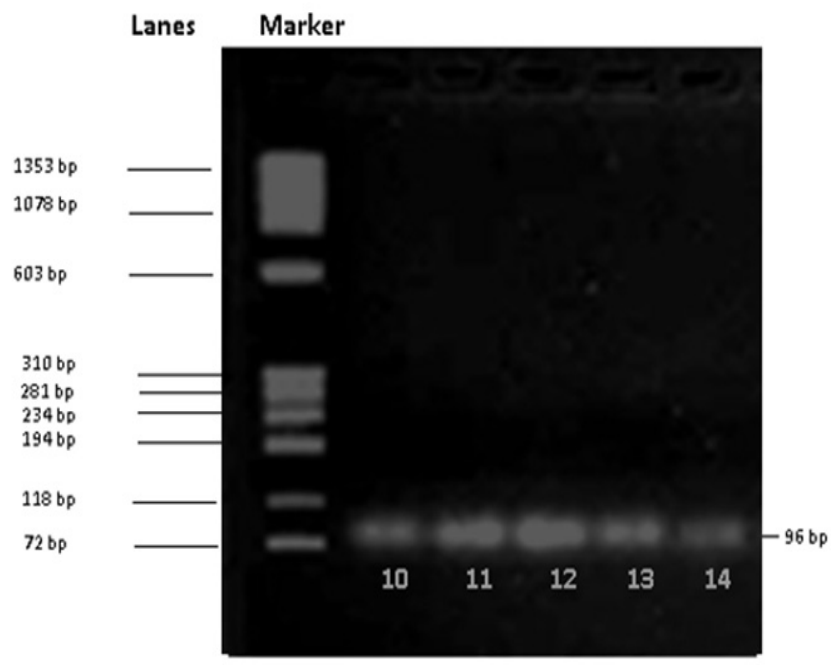

Figure 2: Amplification $\mathrm{P}^{53}$ gene from extracted of DNA from treated animals. Lane M: IX-174 DNA marke Lane 10, 11 and 12 treatment (D) Lane 13 and $14=$ treatment (E)

\section{Histopathological Study}

The animals were killed for autopsy just before death and after appearance of symptoms. Sample of liver, lung and kidney were taken after 2 and 6 weeks, and placed in sample tube containing $10 \mathrm{ml}$ of $10 \%$ formaline then kept in refrigerator for 24 hrs the organs were transferred, without formaline to performed capsules. All capsules were placed into the automatically operated auto-technically apparatus, where basket was surrounded by $10 \%$ formalin solution for 6-8 hrs. Successive series of alcohol was automatically followed with one hour and finally the basket immersed in absolute alcohol for two hrs to completely dehydrate the organs. After dehydration of the specimens, the basked is automatically moved to xylene for another two hrs, then the organ was infiltrated for about four hours with paraffin, after being transferred from the clearing (xylene). The paraffin (melting point $52-56^{\circ} \mathrm{C}$ ) was made into block by the help of two L-shaped metal bars following paraffin- block hardening, the blocks containing the specimens, were attached to wooden object holder and inserted into a microtome. Sections were cut at thickness of $5 \mu \mathrm{m}$. These sections were placed on albumin coated slides which were backed over night at $56^{\circ} \mathrm{C}$, then the micro sections were stained.

\section{Liver function determination}

Blood samples were collected from the reto-orbital plexus from the different rats represent different treatment. Heparin as anticoagulant was used in concentration of $10 \mathrm{IU} / \mathrm{ml}$. The samples were centrifuged at 3500 r.p.m for $15 \mathrm{~min}$ to separate the plasma. GPT (glutamic pyruvic transaminase), alkaline phosphatase concentration [14], Bilirubin concentration [15], cholesterol concentration [16], were determined in plasma using commercially available kits which were obtained from Diamond (Germany). ALT (Alanine aminotransferase), GOT (Glutamic oxaloacetic transaminase) Aspartate aminotransferase (AST) [17] were determined by QCA kits, Spain. The various analysis 
were conducted regarding the standard methods described in each kit.

\section{Statistical analysis of the data}

The data which were obtained from the seven groups were subjected to the statistical analysis. Regarding that, the data represent different non-related experiments, so each treatment was statistically analyzed separately. And each data set contained the seven used group (as described above). In addition, each group under each experiment (e.g. ALP) was represented by five replica.

The data of each group which represent the control (no acrylamid or amino acids), the treatment (no amino acids) and A, B, C, D, E, (amino acids different diets and acrylamide are received) were arranged for each in one column contain the result of five replicas in the Statgraphics Centrium XV version 15.2.11 (7 columns of data).

The final sheet for each group contains five replica represent each of the control, the treatment, and five groups with diets with different composition of the amino acids.

From the Statwizard the option of "compare several data columns using multiple data columns" was selected. Then the groups were selected and the statistical analysis using LSD were generated where the method being used to discriminate among the means is Fisher's least significant difference (LSD) procedure. With this method, there is a $5.0 \%$ risk of calling each pair of means significantly different when the actual difference equals 0 . The software enable conducting ANOVA analysis for the 7 columns of data for each biochemical analysis results as well as for the weight differences. Cluster analysis using the cluster analysis option were conducted to show any link between the groups, which are close to the control (normal cells).

\section{Results and Discussion}

Amino acids are the backbone of any protein existed in the biological structure, including the cancer cells macromolecules. Their numbers, types, distribution are critical for the protein structure/function/specificity. Cancer cells are immunologically and collectively similar to the normal cells. For that, the body did not consider cancer cells as foreigner. Our bodies are unable to produce certain number of amino acids, which should be provided from exogenous source. Cancer and normal cells are in need for the amino acids to build their protein constituents. However, cancer cells need more amino acids than the normal cells do, while cancer cells are growing and replicating faster than the normal cells.

\section{Evaluation of $\mathrm{p}^{53}$ gene as cancer marker using PCR in treated animals with acrylamide and amino acids}

The $\mathrm{p}^{53}$ is one of the most important tumor suppressor proteins [21]. $\mathrm{p}^{53}$ function was associated with human cancers, indicating that $\mathrm{p}^{53}$ plays a key role in the anticancer pathway [22]. $\mathrm{p}^{53}$ is a transcriptional factor and exerts most of its tumor suppressor activities as a transcriptional factor on the regulation of cell cycle arrest. The $\mathrm{p}^{53}$ protein plays a key role in the control of the cell response to various kinds of stress. The expressed genes in the treated and non-treated animals was studied using RT-PCR; the band intensity considered as indicator for the level of the gene expression. The high band intensity means the high $\mathrm{p}^{53}$ gene expression; where the low band intensity indicates of the $\mathrm{p}^{53}$ suppression. The results revealed that, a high band expression was demonstrated with the treated animals with the acrylamide in lane no. (3) Compared with the control.

\section{Internal Organs Weight}

Data in table 4 demonstrate that, treatment with acrylamide increased the absolute liver, lung and kidney weight in rats after 90 days of administration compared with the control and decreased of weight after the animal had feed on the amino acids. In case of the liver, we noticed that the liver size mean in control animal was $(3.8180 \mathrm{~g})$ where in the treated animals with acrylamide was (4.2080 g). However, in the treatment animals with amino acids group (A, B, C, D, and E) the mean weight of the liver were (4.1760, $4.1340,3.8380,3.9260$ and $3.8420 \mathrm{~g}$ ) respectively as showed in table 4 . In case of the lung, we noticed that the lung size mean in control animal was $(0.9040 \mathrm{~g})$ wherever in the treatment animals with acrylamide was $(1.5240 \mathrm{~g})$. But in the treatment animals with amino acids group (A, B, C, D, and E) the mean weight of

Table 2: The bilirubin, cholesterol, ALK, GOT, and GPT biochemical analysis of the seven used groups

\begin{tabular}{|c|c|c|c|c|c|c|c|c|c|c|c|c|c|c|c|}
\hline \multirow[b]{2}{*}{ Sample } & \multicolumn{3}{|c|}{$\begin{array}{c}\text { bilirubin level of } \\
\text { white albino rats } \\
\text { (mg/Di) }\end{array}$} & \multicolumn{3}{|c|}{$\begin{array}{c}\text { cholesterol level } \\
\text { activity of white albino } \\
\text { rats }(\mathrm{mg} / \mathrm{dI})\end{array}$} & \multicolumn{3}{|c|}{$\begin{array}{c}\text { alkaline phosphatase } \\
\text { activity } u / L\end{array}$} & \multicolumn{3}{|c|}{$\begin{array}{l}\text { GOT activity of white } \\
\text { albino rats }(\mathrm{u} / \mathrm{ml})\end{array}$} & \multicolumn{3}{|c|}{$\begin{array}{l}\text { GPT activity of white } \\
\text { albino rats }(\mathrm{u} / \mathrm{ml})\end{array}$} \\
\hline & Mean & Std. D & Std. E & Mean & Std. D & Std. E & Mean & Std. D & Std. E & Mean & Std. D & Std. E & Mean & Std. D & Std. E \\
\hline control & 0.09 & 0.03 & 0.01 & 79.12 & 7.85 & 3.51 & 158.95 & 22.69 & 10.15 & 13.98 & 1.08 & 0.48 & 9.46 & 1.99 & 0.89 \\
\hline treatment & 3.76 & 0.92 & 0.41 & 172 & 0.73 & 0.33 & 223.2 & 6.23 & 2.78 & 56.36 & 1.41 & 0.63 & 54.26 & 1.85 & 0.83 \\
\hline A & 1.1 & 0.21 & 0.1 & 133.74 & 1.42 & 0.64 & 157.41 & 1.71 & 0.76 & 24.22 & 2.08 & 0.93 & 24.21 & 5.07 & 2.27 \\
\hline B & 0.38 & 0.08 & 0.04 & 66.43 & 2.51 & 1.12 & 181.89 & 0.68 & 0.3 & 12.96 & 1.96 & 0.88 & 13.92 & 1.78 & 0.8 \\
\hline C & 0.24 & 0.04 & 0.02 & 62.59 & 1.38 & 0.62 & 179.31 & 0.68 & 0.31 & 18.38 & 5.13 & 2.3 & 9.7 & 0.46 & 0.21 \\
\hline D & 0.15 & 0.05 & 0.02 & 49.56 & 2.54 & 1.13 & 166.94 & 16.94 & 7.58 & 12 & 0.91 & 0.41 & 8.78 & 1.16 & 0.52 \\
\hline $\mathbf{E}$ & 0.08 & 0.04 & 0.02 & 69.75 & 15.85 & 7.09 & 179.88 & 10.8 & 4.83 & 10.42 & 1.11 & 0.50 & 8.36 & 0.87 & 0.39 \\
\hline
\end{tabular}


the lung were $(1.49110,1.4220,1.2820,1.0360$ and $0.9620 \mathrm{~g}$ ) respectively as showed in table 4 .

In case of the kidney, we noticed that the kidney size mean in control animal was $(1.1760 \mathrm{~g})$ wherever in the treatment animals with acrylamide was $(1.4440 \mathrm{~g})$. But in the treatment animals with amino acids group (A, B, C, D, and E) the mean weight of the kidney were $(1.4500,1.3460,1.3100,1.2340$ and $1.1340 \mathrm{~g})$ respectively as show in table 4 .

\section{Effect of Complex Amino Acids Imbalance on Growth of Tumor}

In this study, we have used five different groups of amino acids. Group (A) contains a complete collection of amino acids as in the table 1- 3 in material and method. But group (B) lacks methionine amino acid where it is found that decrease in methionine level has a potent effect on tumor growth in addition to decrease in size of tumor and decrease in enzymes till its normal value like, GOT, GPT, ALK, as well as Bilirubin and Cholesterol. Methionine has an important role in the addition of methyl group to DNA, RNA, protein structure decrease in its level of inhibition, DNA, RNA, formation and prevent the tumor growth at the molecular level. Methionine is the principal biological methyl donor via S-Adenosyl-L-Methionine (SAM). SAM can easily transfer its methyl group to a large variety of acceptor substrates including rRNA, tRNA, mRNA DNA, proteins, phospholipides, biological amines, and a long list of small molecules. Low methionine level inhibits the activity of transmethylase that suggested the invasive ability for metastasis be suppressed during methionine starvation [23]. In group (C) there is no valine. It has a great inhibitory effect on Walker-256 carcinosarcoma cells and alterations of intracellular protein synthesis [24]. In addition to inhibitory effect on synthesis of prolactin, which participate in tumor growth. In group (D) methionine/Valine depleted complex amino acids imbalance group, the volume of tumor decreases more than group A, B, C.

The enzymes reach the normal value due to low methionine/ Valine. In group (E) methionine/Valine deplete complex amino acids imbalance with double increase in arginine. The volume of tumor decreases with group A, B, C, D, and the concentration of the enzymes reach the normal. The amino acid arginine has immune activities that are related to increased production of hormones (growth hormone, insulin, and Prolactin) and of polyamine synthesis. It also induces cytokine release or activation of the nitric oxide pathway $[25,26]$. It is the common substrate for two enzymes: arginase and nitric oxide synthase arginase converts L-arginineto L-ornithine, which is the precursor of polyamines. They are essential components of cell proliferation Nitric oxide synthase.

Table 2 shows the results of the different biochemical analysis which represent the Bilirubin, Cholesterol, ALP, GOT and GPT levels against the seven used rats groups. Each group was represented by five replica (data not shown) and summarized as mean, std. D. std. E. The results show that the absence of the amino acids as in case of the treatment group in the presence of the acrylamide give significant increase in all of the level of the biochemical five test.
That means acrylamide is efficient and represent correct toxins. Acrylamide is proved to be mutagen [13]. The most dangerous point that it could be performed from the potato frits. In addition, consumption regularly and daily by many, particularity through the fast foods. In this study, the design was made similar to the vegetarian or those who made fasting particularly for long time or against the protein containing foods. In such case utilizing acrylamide in the food by them will cause severe health problem as proved in the treatment group. The control represents also those who did not receive amino acids through diets but safe from exogenous source of the acrylamide. In such case (the control), the different groups are safe and have significantly lower level of the five biochemical analysis comparing with the treatment (received acrylamide). In the five other groups, which received, all both of the acrylamide and in addition each was received a particular amino acids diet different from the other one. In fact the first group where it receive fifteen amino acids contain all of the essential amino acids, this group might represent the one who feed normally but receive acrylamide through his diet. Apparently, from the data shown by the Acrylamid-different amino acids five used groups there is significant differences between them and between the treatment groups where no amino acids were received. That clearly prove the importance of the amino acids in diluting, protecting or treating the side effect of the acrylamide. And that those who receive amino acids are healthier and more resistant to a toxic compound such as the acrylamide. In additions they show different results based on that they are different in their composition of the amino acids. The results prove that amino acids improve the protection against the acrylamide and they have different protection level. Based on that the five diet of the amino acids are controlled where some amino acids were removed (e.g. five were removed from all groups). In addition group $\mathrm{E}$ has an increased amount in one amino acids where two other (beside the five removed ones) were removed. That all enables some sort of randomization and control, which enable clear variation. For logical interpretation of the result obtained of the data group E in table 2 shows the closest result to the control. That means lesser effect to the side effect of the acrylamide. The weight of the liver, kidney and the lung give similar results where group E was the closest one to the control. In group E arginine was used in more quantity. Arginine is used for treating hepatic coma, for liver function promotion and for ammonia poisoning in Europe. The only test, which did not give good result (similar to the control) it, was the ALP group. Those spot the sensitivity of the alkaline phosphatase to any toxins. Group A, which show the worst result (similar to the treatment) show good result in case of the ALP level but it shows the highest cholesterol level, bilirubin, GOT and GPT. It is suggested that ALP might decreased by the increase of some other elements in the bodies. And that might include one of the increased tested elements (cholesterol level, bilirubin, GOT and GPT). Groups B, C, D and E show lesser cholesterol level than the control. That also proves the critical role of the amino acids in decreasing and/or controlling the cholesterol level. In general, group E show the best similar result to the control, followed by group D then B.

The statistical analysis of the data shows that group D 
Table 3: Statistical analysis (ANOVA with LSD) for the bilirubin, cholesterol, ALK, GOT, and GPT biochemical analysis of the seven used groups

\begin{tabular}{|c|c|c|c|c|c|c|c|c|c|}
\hline \multicolumn{2}{|c|}{$\begin{array}{c}\text { Effect of Acrylamide } \\
\text { (500ug/kg body } \\
\text { weight) and amino } \\
\text { acids treatment on GOT } \\
\text { activity of white albino } \\
\text { rats }(\mathrm{u} / \mathrm{ml}) \text {. }\end{array}$} & \multicolumn{2}{|c|}{$\begin{array}{c}\text { Effect of Acrylamide } \\
\text { (500ug/kg body weight) } \\
\text { and amino acids treatment } \\
\text { on GPT activity of white } \\
\text { albino rats }(\mathrm{u} / \mathrm{ml}) .\end{array}$} & \multicolumn{2}{|c|}{$\begin{array}{c}\text { Effect of Acrylamide } \\
\text { (500ug/kg body weight) } \\
\text { and amino acids treatment } \\
\text { on alkaline phosphatase } \\
\text { activity of white albino } \\
\text { rats }(u / L) .\end{array}$} & \multicolumn{2}{|c|}{$\begin{array}{c}\text { Effect of Acrylamide } \\
\text { (500ug/kg body weight) } \\
\text { and amino acids } \\
\text { treatment onbilirubin } \\
\text { level of white albino rats } \\
\text { ( } \mathrm{mg} / \mathrm{dI}) .\end{array}$} & \multicolumn{2}{|c|}{$\begin{array}{l}\text { Effect of Acrylamide } \\
\text { (500ug/kg body } \\
\text { weight) and amino } \\
\text { treatment on } \\
\text { cholesterol level } \\
\text { activity of white } \\
\text { albino rats (mg/dI). }\end{array}$} \\
\hline Contrast & Difference & Contrast & Difference & Contrast & Difference & Contrast & Difference & Contrast & Difference \\
\hline $\begin{array}{l}\text { control - } \\
\text { treatment }\end{array}$ & $-42.38^{*}$ & $\begin{array}{l}\text { control - } \\
\text { treatment }\end{array}$ & $-44.796^{*}$ & $\begin{array}{l}\text { Control - } \\
\text { Treatment }\end{array}$ & $-64.248^{*}$ & $\begin{array}{l}\text { Control - } \\
\text { Treatment }\end{array}$ & $-3.677^{*}$ & $A-B$ & $67.316^{*}$ \\
\hline control - A & $-10.24^{*}$ & control - A & $-14.746^{*}$ & Control - A & 1.542 & Control - A & $-1.0174^{*}$ & $A-C$ & $71.152^{*}$ \\
\hline control - B & 1.02 & control - B & $-4.458^{*}$ & Control - B & $-22.938^{*}$ & Control - B & -0.2934 & A - control & $54.622^{*}$ \\
\hline control - C & $-4.4^{*}$ & control - C & -0.238 & Control - C & $-20.354^{*}$ & Control - C & -0.1534 & $A-D$ & $84.184^{*}$ \\
\hline control - D & 1.98 & control - D & 0.686 & Control - D & -7.986 & Control - D & -0.0638 & $A-E$ & $63.99^{*}$ \\
\hline control - E & $3.56^{*}$ & control - E & 1.104 & Control - E & $-20.924^{*}$ & Control - E & 0.0108 & $\begin{array}{c}\text { A - } \\
\text { treatment }\end{array}$ & $-38.252^{*}$ \\
\hline $\begin{array}{c}\text { treatment } \\
-\mathrm{A}\end{array}$ & $32.14^{*}$ & treatment - A & $30.05^{*}$ & Treatment - A & $65.79^{*}$ & $\begin{array}{c}\text { Treatment } \\
\text { - A }\end{array}$ & $2.6596^{*}$ & B - C & 3.836 \\
\hline $\begin{array}{l}\text { treatment } \\
\text { - B }\end{array}$ & $43.4^{*}$ & treatment - B & $40.338^{*}$ & Treatment - B & $41.31^{*}$ & $\begin{array}{l}\text { Treatment } \\
\text { - B }\end{array}$ & $3.3836^{*}$ & B - control & $-12.694^{*}$ \\
\hline $\begin{array}{l}\text { treatment } \\
\quad-\text { C }\end{array}$ & $37.98^{*}$ & treatment - C & $44.558^{*}$ & Treatment - C & $43.894^{*}$ & $\begin{array}{c}\text { Treatment } \\
\text { - C }\end{array}$ & $3.5236^{*}$ & B - D & $16.868^{*}$ \\
\hline $\begin{array}{l}\text { treatment } \\
\text { - D }\end{array}$ & $44.36^{*}$ & treatment - D & $45.482^{*}$ & Treatment - D & $56.262^{*}$ & $\begin{array}{l}\text { Treatment } \\
\text { - D }\end{array}$ & $3.6132^{*}$ & B - E & -3.326 \\
\hline $\begin{array}{l}\text { treatment } \\
-\mathrm{E}\end{array}$ & $45.94^{*}$ & treatment - E & $45.9^{*}$ & Treatment - E & $43.324^{*}$ & $\begin{array}{c}\text { Treatment } \\
- \text { E }\end{array}$ & $3.6878^{*}$ & $\begin{array}{c}\text { B - } \\
\text { treatment }\end{array}$ & $-105.568^{*}$ \\
\hline$A-B$ & $11.26^{*}$ & $A-B$ & $10.288^{*}$ & $A-B$ & $-24.48^{*}$ & $A-B$ & $0.724^{*}$ & C - control & $-16.53^{*}$ \\
\hline$A-C$ & $5.84^{*}$ & $A-C$ & $14.508^{*}$ & $A-C$ & $-21.896^{*}$ & $A-C$ & $0.864^{*}$ & $C-D$ & $13.032^{*}$ \\
\hline$A-D$ & $12.22^{*}$ & $A-D$ & $15.432^{*}$ & $A-D$ & -9.528 & $A-D$ & $0.9536^{*}$ & $C-E$ & -7.162 \\
\hline$A-E$ & $13.8^{*}$ & $A-E$ & $15.85^{*}$ & $A-E$ & $-22.466^{*}$ & $A-E$ & $1.0282^{*}$ & $\begin{array}{c}\mathrm{C}- \\
\text { treatment }\end{array}$ & $-109.404^{*}$ \\
\hline B - C & $-5.42^{*}$ & B - C & $4.22^{*}$ & B - C & 2.584 & B - C & 0.14 & $\begin{array}{c}\text { control } \\
-\mathrm{D}\end{array}$ & $29.562^{*}$ \\
\hline B - D & 0.96 & B - D & $5.144^{*}$ & B - D & 14.952 & B - D & 0.2296 & control - E & $9.368^{*}$ \\
\hline$B-E$ & 2.54 & B - E & $5.562^{*}$ & $B-E$ & 2.014 & $B-E$ & 0.3042 & $\begin{array}{l}\text { control - } \\
\text { treatment }\end{array}$ & $-92.874^{*}$ \\
\hline$C-D$ & $6.38^{*}$ & $C-D$ & 0.924 & $C-D$ & 12.368 & C - D & 0.0896 & $\mathrm{D}-\mathrm{E}$ & $-20.194^{*}$ \\
\hline$C-E$ & $7.96^{*}$ & $C-E$ & 1.342 & $C-E$ & -0.57 & $C-E$ & 0.1642 & $\begin{array}{c}\mathrm{D} \text { - } \\
\text { treatment }\end{array}$ & $-122.436^{*}$ \\
\hline D - E & 1.58 & $D-E$ & 0.418 & $D-E$ & -12.938 & $D-E$ & 0.0746 & $\begin{array}{c}\mathrm{E}- \\
\text { treatment }\end{array}$ & $-102.242^{*}$ \\
\hline \multicolumn{2}{|c|}{ +/- Limits3.0862 } & \multicolumn{2}{|c|}{ +/- Limits3.04262 } & \multicolumn{2}{|c|}{ +/- Limits15.1807 } & \multicolumn{2}{|c|}{ +/- Limits0.465156 } & \multicolumn{2}{|c|}{ +/- Limits8.8974 } \\
\hline
\end{tabular}

contains more insignificant changes against the control (similar to the control). The insignificant results are more important in this study while they show the successful effect of the amino acids diets. The more insignificant results could be explained by the fact that the statistical analysis of the data is not able to distinguish between the increase and the decrease in the level of the biochemical tested parameters. The decrease might not represent health problem in some extend but the statistical analysis will consider it as significant results. For that LSD was used to compare each group by each another one. The insignificant results were highlighted in table 3,4 . However, in general both of the logical and the statistical analysis of the data prove that group $\mathrm{E}$ is the best one followed by group D. Each of the Biochemical treatment level of the different used parameters and the weight of the organs prove that group $\mathrm{E}$ is able to give the best result.

The ANOVA table decomposes the variance of the data into two components: a between-group component and a withingroup component. In case of the alkaline phosphatase activity the F-ratio, which in this case equals 18.0387, (is a ratio of the 
Table 4: The weight of the liver, the lung and the kidney of the albino rats different groups

\begin{tabular}{|c|c|c|c|c|c|c|c|c|c|}
\hline \multirow[b]{2}{*}{ Sample } & \multicolumn{3}{|c|}{$\begin{array}{l}\text { liver weight with (gm) of white } \\
\text { albino rats }\end{array}$} & \multicolumn{3}{|c|}{$\begin{array}{l}\text { lung weight with (gm) of white albino } \\
\text { rats }\end{array}$} & \multicolumn{3}{|c|}{$\begin{array}{l}\text { kidney weight with (gm) of white } \\
\text { albino rats }\end{array}$} \\
\hline & Mean & Std. D & Std. E & Mean & Std. D & Std. E & Mean & Std. D & Std. E \\
\hline control & 3.82 & 0.08 & 0.03 & 0.9 & 0.04 & 0.02 & 1.18 & 0.04 & 0.02 \\
\hline treatment & 4.21 & 0.04 & 0.02 & 1.52 & 0.18 & 0.08 & 1.44 & 0.09 & 0.04 \\
\hline A & 4.18 & 0.05 & 0.02 & 1.49 & 0.16 & 0.06 & 1.45 & 0.05 & 0.02 \\
\hline B & 4.13 & 0.04 & 0.02 & 1.42 & 0.11 & 0.05 & 1.35 & 0.02 & 0.01 \\
\hline C & 3.84 & 0.46 & 0.21 & 1.28 & 0.06 & 0.03 & 1.31 & 0.07 & 0.03 \\
\hline D & 3.93 & 0.06 & 0.03 & 1.04 & 0.02 & 0.01 & 1.23 & 0.05 & 0.02 \\
\hline $\mathbf{E}$ & 3.84 & 0.07 & 0.03 & 0.96 & 0.02 & 0.01 & 1.13 & 0.06 & 0.03 \\
\hline
\end{tabular}

between-group estimate to the within-group estimate). In case of bilirubin level the F-ratio, this in this case equals 69.9103. In case of cholesterol level the F-ratio, this in this case equals 213.886. GOT activity the F-ratio, which in this case equals 231.162. GPT activity the F-ratio, which in this case equals 255.125. Lung weight the F-ratio, which in this case equals 43.4766. Kidney weight the F-ratio, which in this case equals 43.4766. Since the $\mathrm{P}$-value of the F-test is less than 0.05 in all the above groups, there is a statistically significant difference between the means of the 7 variables for each group at the $95.0 \%$ confidence level.

This applies a multiple comparison procedure to determine which means are significantly different from which others. The bottom half of the output shows the estimated difference between each pair of means. An asterisk was placed next to twelve pairs, indicating that these pairs show statistically significant differences at the $95.0 \%$ confidence level. The method which used to discriminate among the means is Fisher's LSD procedure. With this method, there is a $5.0 \%$ risk of calling each pair of means significantly different when the actual difference equals 0 .

\section{Histopathological Findings in Treated Rats}

Data concerning the histopathological examinations in the tissues organs of the treated rats with acrylamide for 70 days followed by amino acids treatment. The obtained results showed the effect of both of the acrylamide and amino acids on the tested animal organs and tissues. To facilitate the presentation of data, each organ will be separately discussed as follow:

\section{Liver}

In control sample, histopathological examination of the liver, showed normal liver tissues with hepatocytes sinuso-ids and central vein is present at central port of each lobe, portal tract present peniphry. However, in acrylamide-treated group, showed loss of normal structure of hepatic cords in large areas of liver tissues a combined with malignant hepatocytes showing pleomorphism and hyperchromatism. But in amino acids (A)treated group, malignant criteria at witch malignant hepatocytes arranged in cords and sheets table 7 . Higher magnification clarify malignant hepatocytes with pleomorphism and hyperchromatism whatever the amino acids (B)-treated group, hepatocytes showed little pleomorphism and little hyperchromatism. However the amino acids (C)-treated group, revealed small areas of liver tissue still malignant criteria but most of cells showed monomorphic appearance and number of malignant cells. Amino acids (D)treated group, represent the most of liver tissue look like normal cells may see small numbers of hyperchromatism.

Amino acids (E)- treated group, showed normal structure of hepatic cords of hepatocytes arranged in cords in between hepatic sinusoids with central veins table 7. In previous study, similar changes were observed in the liver showing severe ballooning degeneration of the hepatocytes, necrosis and formation of mallory bodies table 7 [27].

\section{Lung}

In control sample, histopathological examination of the lung, showed lung acinus which composed of respiratory bronchioles which gave several alveoli. However, in acrylamide-treated group, malignant proliferation of epithelial cells producing glandular structure with central lumina, the glands are available in size and shape with great polymorphism and loss of polarity table 7 . There are glands closely packed to each other and some glands are fused. Areas of necrosis represented by eosinophilic fibrous liver amorphous material. Normal alveoli are not seen in the slide. Amino acids (A)-treated group, showed mild improvement in the shape of adenocarcinoma than the previous slide. The glands tend to be separated from each other. The center of some glands tends to be more regular. But the amino acids (B)-treated group, revealed that, there is moderate importance of the shape of malignancy. The number of malignant glands are decreased in size more regular contour and some alveoli are seen. However the amino acids (C)-treated group. Showed there are no abnormal glands and the alveoli with districted walls as well as emphysome in some of them. Amino acids (D)-treated group revealed that the alveoli tend to be more normal but some emphyse are seen table 7. But the amino acids (E)-treated group. Normal alveoli are seen but with edema in the interstitial tissue. In previous study, in the lungs diffused alveolar and capillary damage as well as early formation of hyaline membranes were evident.

\section{Kidney}

In control sample, histopathological examination of the lung, normal kidney tissue contains numerous tubules and 


\section{Table:7}

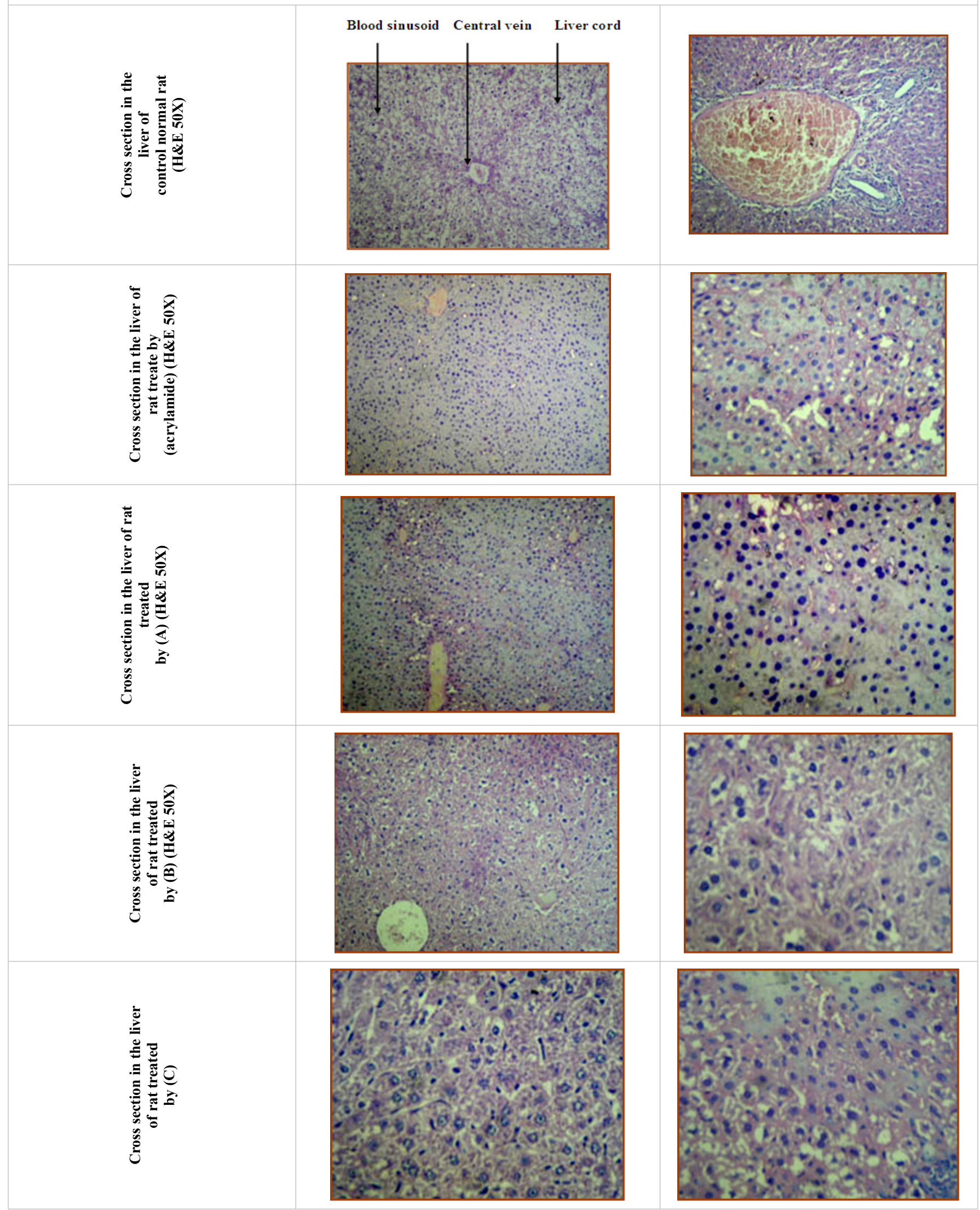




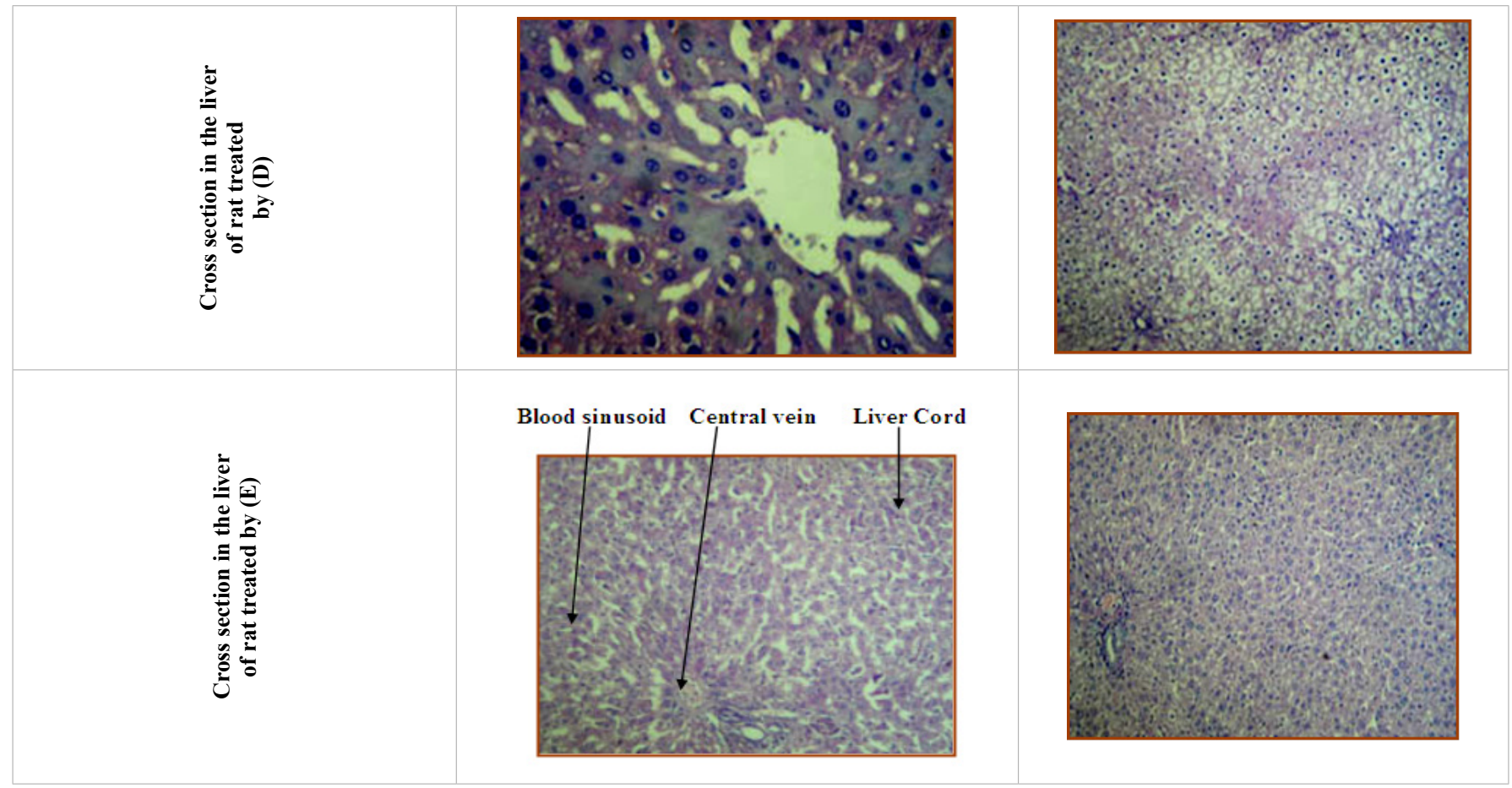

glomeruli separated by vascularized stroma observed. However in acrylamide-treated group, showed tumor formed of cordes and small groups of malignant cells separated by very thin vascula (c.t) storms containing thin walled ill formed (b.v) table 7 the cells are large polyhedral with pale vacuolated cytoplasm giving the clear cell appearance the nuclei are small, central pyknotic and deeply stained there is diffused pattern of growth with entrapping of glomerulus. Amino acids (a)-treated group the slides showed some b.v invade tumor tissue the malignant cells are decreased in size and tubules appears which dilated and lined by flat epithelia but the amino acids (b)-treated group, showed the clear cells are decreased markedly and well formed b.v and well formed tubules appearance. However the amino acids (c)treated group, showed the malignant clear cells but some tubules are atrophic and contain hyaline casts. Amino acids (d)-treated group, normal tubules are seen, and normal lining the hyaline casts are decreased in case of amino acids (e)-treated group, normal tubules normal glomeruli's vascular tuft and clear haloes amount table 7 in previous study, in the kidneys, there was acute tubular necrosis with diffused interstitial and glomerular haemorrhage characteristic of irreversible cellular injury of the epithelium and parenchyma [27].

\section{Conclusions}

This study investigates the role of the amino acids different diet composition in the rats treated by acrylamide. The acrylamide was selected while it exited in the potato frits. The experimental design is based on our aim to investigate if vegetarians might be more susceptible to the side effect of the acrylamide where they receive less aminoacids through diets (they did not eat any of the mammalian meat or their product). Additionally, the study investigates the role of the different amino acids in the protection against the acrylamide different side effects. For that each of the control and the treatment receive no amino acids to evaluate the effect of the acrylamide. After that five different amino acids controlled diets were designed to prove or disprove the essential role of the amino acids in the protection and in the treatment. For evaluating the; effect of both of the acrylamide and the amino acids different results were calculated they are:

a) Five biochemical tests (the cholesterol, the billirobin, ALP, GOT, GPT).

b) The liver, kidney and lung weight

c) The level of the $p^{53}$

d) Histological study for the liver, kidney and lung.

Two tools for the data interpretation were followed. The first based on the logical evaluating of the differences obtained from the various experiments and the other by statistical analysis of the data.

In general the results prove that:

a) The acrylamide is a dangerous compound for the rats health hence for the human.

b) Amino acids free medium (in this study) might not seriously affect the rats health in the short run (the time of the experiments). This represents a fasting or a starvation for a particular period.

c) The amino acids are significantly able to rebalance the disturbance in the animal biological function (investigated ones) due to the effect of the acrylamide.

d) Different amino acids compositions give different results. The best one which contain a removal of seven amino acids from the diet (group E) as in Tables 1-6. 
Table 5: The statistical analysis of the weight of the liver, the lung and the kidney of the albino rats different groups

\begin{tabular}{|c|c|c|c|c|c|}
\hline \multicolumn{2}{|c|}{$\begin{array}{c}\text { Effect of Acrylamide }(500 \mathrm{ug} / \mathrm{kg} \text { body weight) } \\
\text { and amino acids treatment on liver weight } \\
\text { with (gm) of white albino rats }\end{array}$} & \multicolumn{2}{|c|}{$\begin{array}{l}\text { Effect of Acrylamide }(500 \mathrm{ug} / \mathrm{kg} \text { body } \\
\text { weight) and amino acids treatment on } \\
\text { lung weight with (gm) of white albino rats }\end{array}$} & \multicolumn{2}{|c|}{$\begin{array}{l}\text { Effect of Acrylamide (500ug/kg body } \\
\text { weight) and amino acids treatment on } \\
\text { kidney weight with (gm) of white albino rats }\end{array}$} \\
\hline Contrast & Difference & Contrast & Difference & Contrast & Difference \\
\hline $\begin{array}{l}\text { control - } \\
\text { treatment }\end{array}$ & $-0.39^{*}$ & $\begin{array}{l}\text { control - } \\
\text { treatment }\end{array}$ & $-0.62^{*}$ & control - treatment & $-0.62^{*}$ \\
\hline control - A & $-0.358^{*}$ & control - A & $-0.654^{*}$ & control - A & $-0.654^{*}$ \\
\hline control - B & $-0.316^{*}$ & control - B & $-0.518^{*}$ & control - B & $-0.518^{*}$ \\
\hline control - C & -0.02 & control - C & $-0.378^{*}$ & control - C & $-0.378^{*}$ \\
\hline control - D & -0.108 & control - D & $-0.132^{*}$ & control - D & $-0.132^{*}$ \\
\hline control - E & -0.024 & control - E & -0.058 & control - E & -0.058 \\
\hline treatment - A & 0.032 & treatment - A & -0.034 & treatment - A & -0.034 \\
\hline treatment - B & 0.074 & treatment - B & 0.102 & treatment - B & 0.102 \\
\hline treatment - C & $0.37^{*}$ & treatment - C & $0.242^{*}$ & treatment - C & $0.242^{*}$ \\
\hline treatment - D & $0.282^{*}$ & treatment - D & $0.488^{*}$ & treatment - D & $0.488^{*}$ \\
\hline treatment - E & $0.366^{*}$ & treatment - E & $0.562^{*}$ & treatment - E & $0.562^{*}$ \\
\hline$A-B$ & 0.042 & $A-B$ & $0.136^{*}$ & $A-B$ & $0.136^{*}$ \\
\hline A - C & $0.338^{*}$ & $A-C$ & $0.276^{*}$ & $A-C$ & $0.276^{*}$ \\
\hline$A-D$ & $0.25^{*}$ & $A-D$ & $0.522^{*}$ & $A-D$ & $0.522^{*}$ \\
\hline$A-E$ & $0.334^{*}$ & $A-E$ & $0.596^{*}$ & $A-E$ & $0.596^{*}$ \\
\hline B - C & $0.296^{*}$ & B - C & $0.14^{*}$ & B - C & $0.14^{*}$ \\
\hline B - D & 0.208 & B - D & $0.386^{*}$ & B - D & $0.386^{*}$ \\
\hline$B-E$ & $0.292^{*}$ & $B-E$ & $0.46^{*}$ & $B-E$ & $0.46^{*}$ \\
\hline C - D & -0.088 & C - D & $0.246^{*}$ & C - D & $0.246^{*}$ \\
\hline$C-E$ & -0.004 & $C-E$ & $0.32^{*}$ & $C-E$ & $0.32^{*}$ \\
\hline$D-E$ & 0.084 & $D-E$ & 0.074 & $\mathrm{D}-\mathrm{E}$ & 0.074 \\
\hline \multicolumn{2}{|c|}{ +/- Limits 0.235253} & \multicolumn{2}{|c|}{ +/- Limits0.120112 } & \multicolumn{2}{|c|}{ +/- Limits0.120112 } \\
\hline
\end{tabular}

Table 6: Cluster analysis of the different groups
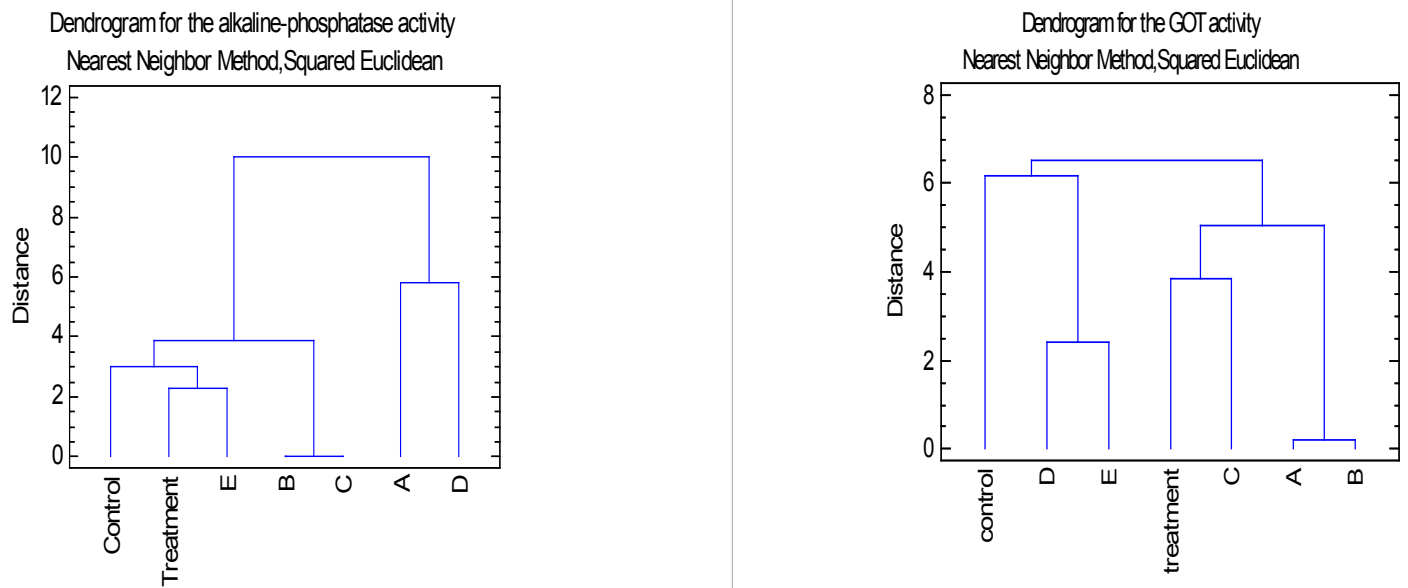

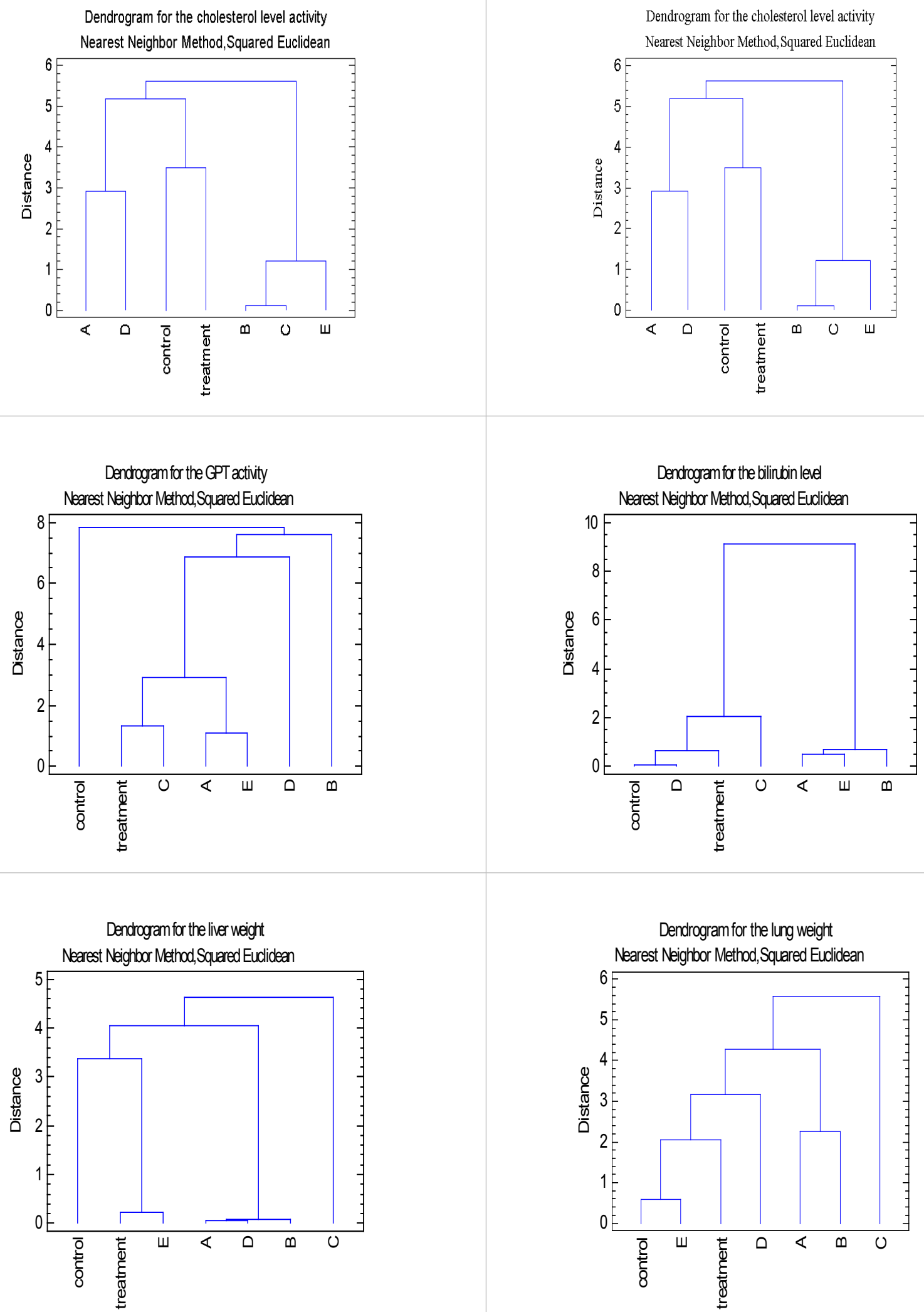

Citation: Hamad GM, Hafez EE, et al. (2018) Amino Acids Diets as Model for Investigating Cancer Induced by Acrylamide Produced during Wrong Food Cooking. SOJ Biochem 4(1): 1-14. http://dx.doi.org/10.15226/2376-4589/4/1/00126 


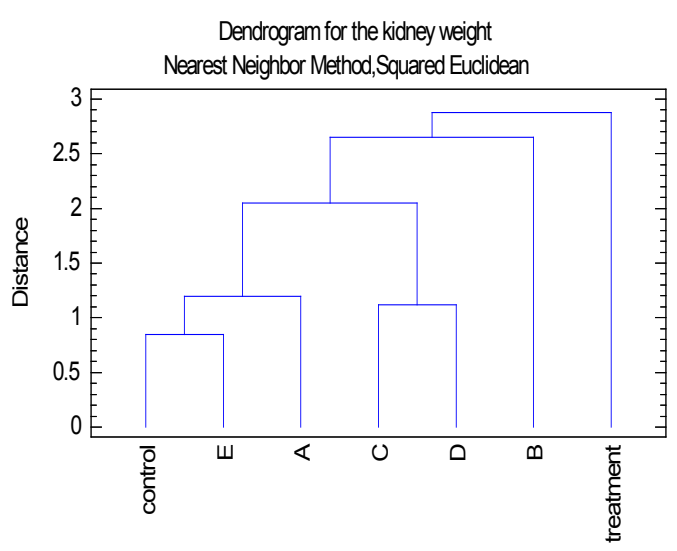

e) The amino acids used biochemical parameters prove to be so sensitive particularly the ALP.

f) The presence of the amino acids in the diets can improve significantly the liver function and can adjust the cholesterol level.

g) Apparently, the amino acids play more roles than we know in the balance of the physiological and the bio-chemical properties of the rats hence the human.

\section{Recommendations}

Those who are vegetarian or fasting for log time might be safe if not received compounds able to affect on the body organs such as the acrylamide (presence in potato frits).

And they are more susceptible than those receive amino acids through diets.

Amino acids controlled diets should be find more attention either for the aim of the protection, health improvement or in the treatment of some diseases including the cancer.

This study investigates the role of the amino acids different composition in the rats treated by acrylamide. The acrylamide was selected while it existed during the eating of the potato frits. The experimental design is based on our aim to investigate if vegetarian or those how starve or fast from protein containing food are susceptible to the side effect of the acrylamide based on the fact that they receive lesser amino acids. Additionally, the study investigates the role of different amino acids in the protection against the acrylamide side effect. For that each of the control and the treatment receive no amino acids and represent those who keep amino acids away from their diets but not receive/ or receive acrylamide in their food. To prove/or disprove the role of the controlled diets in the protection, treatment of the toxic (as well as the carcinogenic) side effect of the acrylamide five different diets contain different amino acids were used.

\section{Conflict of Interest}

The authors have no conflict of interests to declare.

\section{Financial Disclosure}

Institutional support

\section{Acknowledgement}

The authors acknowledges anyone who support the PhD; Thesis of Dr. Gamal M. Hamad titled "Genetic transformation in Corynebacterium glutamicum for overproduction some bioapplicable amino acids" which conducted in both of the City of Scientific Research and Technological Applications and in the Faculty of Agric. (Saba-Bacha) Alexandria University. The authors acknowledge anyone who by any means support this study in the each of the Cairo, Alexandria and Ain Sams Universities as well as in the City of Scientific Research and Technological Applications.

\section{References}

1. Salo M, Kiviranta J, Knuutila V, Kangas L, Vuorela H. Biological activity and enzymatic hydrolysis of retinoates in vitro. Eur J Pharm Sci. 1995;3(2):71-76.

2. Dethlefsen LA, JMS Prewitt, ML Mendelsohn. Analysis of tumor growth curves. J Nat Cancer Inst. 1968;40(2):389-405.

3. White FR, M Belkin. Source of tumor proteins. I. Effect of a low-nitrogen diet on the establishment and growth of a transplanted tumor. J Nat Cancer Inst. 1945;5(4):261-263.

4. Skipper HE, JR Thomson. Amino Acids and Peptides with Antimetabolic Activity. Little, Brown and Co. 1958:38-53.

5. Sugimura T, SM Birnbaum, M Winitz, JP Greenstein. Quantitative nuᄀtritional studies with water-soluble, chemically defined diets. VIII. The forced feeding of diets lacking in one essential amino acid. Arch Biochem Biophys. 1959;81(2):448-455.

6. Lorincz $\mathrm{AB}$, and RE Kuttner. Response of malignancy to phenylalanine reרstriction; a preliminary report on a new conาcept of managing malignant disease. Nebr State Med J. 1965;50:609.

7. Demopoulos HB. Effects of reducing the phenylalanine-tyrosine intake of patients with advanced malignant melanoma. Cancer. 1966;19(5):657-664.

8. Hanahan D, Weinberg RA. The hallmarks of cancer. Cell. 2000;100(1):5770 .

9. Hanahan D, Weinberg RA. Hallmarks of cancer: the next generation. Cell. 2011;144(5):646-674. doi: 10.1016/j.cell.2011.02.013

10.Amara A. Cancer and anticancer: A discussion. Schüling Verlag, Germany, 2011. 
11.Amara A. Toward healthy genes. Schüling Verlage, Germany, 2012.

12.Amara A. Methods other than Experimental Animals for Screening Antitumor Compounds. American Journals of Cancer Science. 2013;2(1).

13.Yousef MI, El-Demerdash FM. Acrylamide-induced oxidative stress and biochemical perturbations in rats. Toxicology. 2006;219(1-3):133-141. doi: 10.1016/j.tox.2005.11.008

14.Belfield A and Goldberg DM. Normal ranges and diagnostic value of serum $5^{\prime}$ nucleotidase and alkaline phosphatase activities in infancy. Arch Dis Child. 1971;46(250):842-846.

15.Walter M and Gerade H. Determination of the "Total"bilirubin and its conjugated "Direct” fraction. Micro chem J. 1970;15:231.

16.Richmond W. Preparation and properties of a cholesterol oxidase from Nocardia sp. and its application to the enzymatic assay of total cholesterol in serum. Clin Chem. 1973;19(12):1350-1356.

17.Reitman S, FRANKEL S. A colorimetric method for the determination of serum glutamic oxalacetic and glutamic pyruvic transaminases. Am J Clin Pathol. 1957;28(1):56-63.

18.Helms C. Salting out procedure for human DNA extraction. In The DonisKeller Lab - Lab Manual Homepage [online]. 24 April 1990.

19.Charles RaC T. Quantitive analysis of DNA and RNA. Nucleic Acids Symposium. 2008;52(1):15.
20.Sambrook J, Fritsch EF \& Maniatis T. Molecular Cloning. a Laboratory Manual, 2nd edn. Cold Spring Harbor, NY: Cold Spring Harbor Laboratory. 1989.

21.Vousden KH, Prives C. $\mathrm{p}^{53}$ and prognosis: New insights and further complexity. Cell. 2005;120(1):7-10.

22.Riley KJ, Cassiday LA, Kumar A, Maher LJ 3rd. Recognition of RNA by the $\mathrm{p}^{53}$ tumor suppressor protein in the yeast three-hybrid system. RNA. 2006;12(4):620-630.

23.Shelly C. Lu. Methionine adenosyltransferase and liver disease: It's all about SMA. Gastroenterology. 1998;114(2):403-407.

24.He YC, Wang YH, Cao J, Chen JW, Pan DY, Zhou YK. Effect of complex amino acid imbalance on growth of tumor in tumor-bearing rats. World J Gastroenterol. 2003;9(12):2772-2775.

25.Snow EC. Insulin and growth hormone function as minor growth factors that potentiate lymphocyte activation. J Immunol. 1985. 135: 776s-778s.

26.Hartmann DP, Holaday JW, Bernton EW. Inhibition of lymphocyte proliferation by antibodies to prolactin. FASEB J. 1989;3(10): 2194-2202.

27.Maxwell D.L, JAC; Noel WN; Steven GS; and Naanlep TM. The histopathologic effects of Securidaca longepedunculata on heart, liver, kidney and lungs of Rats. African Journal of Biotechnology. 2009;591-595. 